\title{
Workplace flourishing: Measurement, antecedents and outcomes
}

\begin{tabular}{|c|c|}
\hline $\begin{array}{l}\text { Authors: } \\
\text { Kleinjan Rede } \\
\text { Sebastiaan Ro } \\
\text { Elrie Botha }{ }^{2}\end{array}$ & $\begin{array}{l}\text { inghuys }{ }^{1} \text { (D) } \\
\text { thmann }{ }^{1}\end{array}$ \\
\hline $\begin{array}{l}\text { Affiliations: } \\
{ }^{1} \text { Optentia Res } \\
\text { Area, North- } \\
\text { South Africa }\end{array}$ & $\begin{array}{l}\text { earch Focus } \\
\text { lest University, }\end{array}$ \\
\hline $\begin{array}{l}{ }^{2} \text { School of Ind } \\
\text { Psychology an } \\
\text { Resource Mar } \\
\text { Optentia Rese } \\
\text { Area, North-V } \\
\text { South Africa }\end{array}$ & $\begin{array}{l}\text { ustrial } \\
\text { d Human } \\
\text { agement, } \\
\text { arch Focus } \\
\text { lest University, }\end{array}$ \\
\hline $\begin{array}{l}\text { Correspondin } \\
\text { Kleinjan Rede } \\
\text { 21887217@n }\end{array}$ & $\begin{array}{l}\text { author: } \\
\text { inghuys, } \\
\text { vu.ac.za }\end{array}$ \\
\hline $\begin{array}{l}\text { Dates: } \\
\text { Received: } 06 \text { I } \\
\text { Accepted: } 02 \\
\text { Published: } 09\end{array}$ & $\begin{array}{l}\text { hay } 2018 \\
\text { ept. } 2018 \\
\text { Jan. } 2019\end{array}$ \\
\hline $\begin{array}{l}\text { How to cite th } \\
\text { Redelinghuys, } \\
\text { Rothmann, S., } \\
\text { (2019). Workp } \\
\text { flourishing: M } \\
\text { antecedents a } \\
\text { SA Journal of } \\
\text { Psychology/S } \\
\text { Bedryfsielkun } \\
\text { a1549. https:/ } \\
\text { 10.4102/sajip }\end{array}$ & $\begin{array}{l}\text { is article: } \\
\text { K., } \\
\text { \& Botha, E. } \\
\text { lace } \\
\text { easurement, } \\
\text { nd outcomes. } \\
\text { ndustrial } \\
\text { Tydskrif vir } \\
\text { le, 45(0), } \\
\text { /doi.org/ } \\
\text { v45i0.1549 }\end{array}$ \\
\hline $\begin{array}{l}\text { Copyright: } \\
\text { (c) 2019. The } \\
\text { Licensee: AOS } \\
\text { is licensed un } \\
\text { Creative Comr } \\
\text { Attribution Lio }\end{array}$ & $\begin{array}{l}\text { uthors. } \\
\text { S. This work } \\
\text { ler the } \\
\text { nons } \\
\text { ense. }\end{array}$ \\
\hline Read online: & \\
\hline 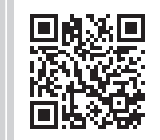 & $\begin{array}{l}\text { Scan this QR } \\
\text { code with your } \\
\text { smart phone or } \\
\text { mobile device } \\
\text { to read online. }\end{array}$ \\
\hline
\end{tabular}

Orientation: The continuous growth of employee attrition, especially within the highly skilled talent pool, is becoming increasingly problematic. Therefore, one should continually explore the different factors that impact employee retention and performance. This casts the attention to the person-environment fit and workplace flourishing (WF).

Research purpose: This study explored relationships among person-environment fit, WF, intention to leave (ITL), in-role performance and organisational citizenship behaviour.

Motivation for the study: Disease-driven research heavily outweighs health promotion research. Therefore, more research is needed regarding positive employee behaviours such as strengths, optimal functioning and flourishing.

Research approach/design and method: A cross-sectional survey design was used with 258 secondary school teachers from two Gauteng districts. The Perceived Fit, Flourishing-at-Work, Turnover Intention, In-Role Behaviour and Organisational Citizenship Behaviour scales were administered. Structural equation modelling and mediational analyses were performed.

Main findings: Results confirmed WF's three-factor structure. Person-environment fit positively associated with WF. Workplace flourishing negatively related to ITL, while positively relating to in-role performance and organisational citizenship behaviour. Person-environment fit indirectly affected in-role performance and organisational citizenship behaviour via WF.

Practical/managerial implications: Organisations should continually modify their strategic frameworks to maintain a healthy balance between individual and environmental characteristics. This will lay the foundation for a favourable work environment. When such an environment is institutionalised, talent retention and performance should follow.

Contribution/value-add: The study results should provide new insight into the relationship between the person-environment fit and WF, as well as the effect it may have on ITL and performance.

\section{Introduction}

The continuous growth and manifestation of employee attrition, especially within the highly skilled talent pool, is becoming increasingly problematic. When organisations establish policies that retain productive personnel, remove unproductive personnel and select the most suitable new candidates, they should have a favourable composition of qualified and talented employees (Adnot, Dee, Katz, \& Wyckoff, 2017). Thus, two factors are emphasised: employee retention and employee performance. To address this persisting issue, researchers need to establish different factors that impact employee retention and employee performance, factors in addition to wellestablished disease-driven aspects such as stress, burnout and depression (e.g. Steinhardt, Smith Jaggars, Faulk, \& Gloria, 2011). Although the preceding aspects are undeniably significant in their own right, they tend to ignore or fail in furthering our understanding of the role flourishing plays in employee well-being (Youssef-Morgan \& Luthans, 2014).

The concept of flourishing in life (Keyes, 2002) has positioned itself as the most prominent multidimensional well-being model (Keyes, 2002; Seligman, 2011). Building on the study of Keyes (2002), Rothmann (2013) studied the multidimensionality of flourishing, comprising emotional well-being, psychological well-being and social well-being in work and organisational contexts. Workplace flourishing (WF) has been defined as an employee's perception that he or she is feeling and functioning well in the workplace (Rautenbach, 2015).

Note: This article is partially based on the author's thesis for the degree Doctor of Philosophy in Industrial Psychology at the North-West University (Vaal Triangle Campus), South Africa, with promoter Prof. S. Rothmann and co-promoter Dr E. Botha, November 2016, available here: http://dspace.nwu.ac.za/bitstream/handle/10394/24959/Redelinghuys_JJ.pdf?isAllowed=y\&sequence=1 
Using the Flourishing-at-Work Scale (FAWS; Rautenbach, 2015), Janse van Rensburg, Rothmann, and Diedericks (2017) found that person-environment fit relates (PEF) positively with flourishing and negatively with intention to leave (ITL) via flourishing. However, the effects of WF (in addition to PEF) on other organisational outcomes have not been studied. Moreover, the social well-being scale of the FAWS as developed by Rautenbach (2015) and used by Janse van Rensburg et al. (2017) included only one item per social well-being dimension. Therefore, it is vital to investigate additional factors associated with WF to strengthen the FAWS's psychometric properties.

The study aim was to examine relationships among PEF, WF, ITL, in-role performance and organisational citizenship behaviour (OCB).

\section{Flourishing at work}

Emotional well-being incorporates three employee judgements: job satisfaction, positive emotions and negative emotions. Job satisfaction reflects the amount of congruence between employees' perceptions and standards (Weiss \& Cropanzano, 1996). Positive affect stands key towards an individual's capacity to flourish. It refers to pleasant reactions at work (e.g. joy, interest, and gratitude), while negative affect encompasses unpleasant reactions (e.g. sadness, boredom and anxiety). Although both job satisfaction and affect tap into employee emotions, the focus of the constructs differs slightly, making both constructs valuable flourishing components. Job satisfaction reveals employees' perceptions that their wants are attended to, while affect relates to employees' perceptions that their needs are attended to (Rojas \& Veenhoven, 2013).

Psychological well-being at work includes dimensions (autonomy, personal growth, mastery, meaning, purpose and positive relations) in Ryff and Singer's (1998) model, as well as engagement (Seligman, 2011). Three dimensions in the model of Ryff and Singer (1998) relate to three psychological needs (Deci \& Ryan, 1985), namely autonomy (i.e. autonomy satisfaction - experiencing independence and choice in executing work-related tasks), mastery (i.e. competence satisfaction - feeling effective in work environment interaction) and positive relations (i.e. relatedness satisfaction - experiencing a sense of connectedness to others in the workplace). Meaning reflects the perceived significance of employees' work experiences, while purpose refers to possessing a sense of the preferred outcomes connected to one's work-related behaviour (Barrick, Mount, \& Li, 2013). Learning (similar to personal growth in the model of Ryff \& Singer, 1998) is defined as the acquisition and application of knowledge and expertise to one's job (Spreitzer, Lam, \& Fritz, 2010). Finally, work engagement comprises three components, namely a physical component (involvement and the exhibition of vitality), a cognitive component (absorption and involvement) and an affective component (connectedness to one's job and dedication) (Kahn \& Heaphy, 2014).
Social well-being includes five dimensions: social acceptance (the acceptance of the diversity of colleagues), actualisation (the belief in one's organisation, team and colleagues' potential), coherence (the belief that one's organisation and social relations at work are both meaningful and comprehensible), contribution (the belief that one's daily work tasks add value to one's team, department, and organisation) and integration (the belief that one experiences a sense of communal connectedness and belongingness) and the mental health continuum (MHC) (Keyes, 1998, 2005). The social element of work plays a pivotal part in flourishing (Grant, 2008), as employees are embedded within social organisational structures, facing endless social tasks and challenges (Keyes, 1998).

\section{Person-environment fit, workplace flourishing, intention to leave and performance}

Fishbein and Ajzen (1975) contend that beliefs precede attitudes, intentions and ultimately behaviours. Metaanalytic studies (Hoffman \& Woehr, 2006; Kristof-Brown, Zimmerman, \& Johnson, 2005; Oh et al., 2014; Verquer, Beehr, \& Wagner, 2003) suggest that person-organisation and person-job fit generally has a strong association with attitudes (e.g. job satisfaction), while having a weaker association with intentions (e.g. ITL) and behaviours (e.g. in-role, extra-role). Therefore, although PEF strongly relates to important job attitudes, intervening variables may be required to amplify its association with intention and behaviour. A feasible intervening variable in the relationship between PEF and the outcomes contained in this study (ITL, in-role performance, and organisational citizenship behaviour $[\mathrm{OCB}]$ ), could be WF. WF contains various components that directly link to PEF and the study outcome, as well as numerous components that could mediate fitoutcome relationships.

Cable and DeRue (2002) adopted a three-factor personenvironment fit conceptualisation (person-organisation, needs-supplies, and demands-abilities). Person-organisation fit reflects the degree of perceived similarity in terms of values between employees and organisations (Cable \& DeRue, 2002). Employees feel attached to the organisation's broader mission when they believe that their values match that of their organisation and colleagues. Employees form separate cognitions regarding organisational and job-related fit. Needs-supplies fit reflects the perceived similarity between job rewards (what the organisation offers) and employee needs (Cable \& DeRue, 2002). When employees perceive a match between what they expect from their job and what they receive, job satisfaction materialises (Dawis \& Lofquist, 1984; Locke, 1976). Demands-abilities fit reflects the perceived similarity between job demands and an employee's inhabited knowledge, skills and capabilities (Cable \& DeRue, 2002).

Traditionally, fit literature posits that if congruence is reached between the employee and the work environment, positive outcomes ensue. The work adjustment theory 
(TWA; Dawis \& Lofquist, 1984) and job embeddedness theory (Mitchell, Holtom, Lee, Sablynski, \& Erez, 2001) suggest that when congruence is achieved between employees and their work environment and when employees establish meaningful relationships in the workplace, they will experience increased satisfaction, which will subsequently affect their turnover decisions. For instance, job satisfaction (an emotional well-being element) plays a central part in various employee turnover models (Hom, Lee, Shaw, \& Hausknecht, 2017), suggesting that dissatisfied employees will start to explore other possibilities through a range of evaluation processes. Similarly, the attractionselection-attrition (ASA) model (Schneider, 1987) suggests that employees are attracted to and remain within organisations with which they share similar preferences, as this allows them to achieve their goals. Regarding social well-being, the social identity theory (Tajfel \& Turner, 1986) proposes that employees who experience fit with their organisation's values become part of a psychological group, defined as the 'collection of people who share the same social identification or define themselves in terms of the same social category membership' (Turner, 1984, p. 530). Therefore, when employees experience a favourable balance between their personal (values, abilities and needs) and environmental characteristics (values, demands and supplies), it lays the foundation for a positive work environment. Within this environment, employees may experience a sense of acceptance, enjoyment, integration, meaningfulness and relatedness, among others (Janse van Rensburg et al., 2017). Subsequently, employees should experience little to no urge to leave their work setting (Janse van Rensburg et al., 2017). Intention to leave is defined as an employee's cognisant and intentional frame of mind to part ways with his or her organisation (Tett \& Meyer, 1993).

Apart from the preceding frameworks, various studies suggest that PEF links to WF elements, including job satisfaction (Cable \& DeRue, 2002), positive affect (Gabriel, Diefendorff, Chandler, Moran, \& Greguras, 2014), meaningful work (Duffy, Autin, \& Bott, 2015), psychological need satisfaction (Greguras \& Diefendorff, 2009) and work engagement (Chen, Yen, \& Tsai, 2014). Subsequently, studies also link various WF elements to ITL, including affect (Thoresen, Kaplan, Barsky, Warren, \& De Chermont, 2003), work engagement (Alarcon \& Edwards, 2011), job satisfaction (Redelinghuys \& Botha, 2016) and meaningful work (Janik \& Rothmann, 2015); while PEF has indirectly affected ITL via job satisfaction (Wheeler, Gallagher, Brouer, \& Sablynski, 2007), work engagement (Peng, Lee, \& Tseng, 2014) and more recently WF (Janse van Rensburg et al., 2017).

Apart from ITL, in-role performance and OCB have also been associated with WF (Redelinghuys, Rothmann, \& Botha, 2018). In-role performance refers to the undertakings an employee is expected to fulfil as stipulated in his or her formal job requirements (Borman \& Motowidlo, 1997; Williams \& Anderson, 1991). In contrast, Lambert (2006) defines $O C B$ as employee behaviour that contributes beyond what is expected in the basic job requirements. Four dimensions constitute OCB: helping, loyalty, advocacy, as well as functional participation and obedience (CoyleShapiro, 2002; Van Dyne, Graham, \& Dienesch, 1994). Helping reflects the extent to which employees offer assistance to others. Loyalty relates to the identification with or loyalty towards the organisation, which involves cooperation and serving the organisational interests. Advocacy refers to behaviour aimed at others in the organisation, which includes the maintenance of high standards, the challenging of others and the proposition of change. Functional participation assumes a more personal stance, while simultaneously contributing to organisational efficiency (Coyle-Shapiro, 2002; Van Dyne et al., 1994).

Although the association between WF, in-role performance and OCB has been studied before (Redelinghuys et al., 2018), the indirect effect of PEF on performance (in-role and extra-role) via WF is yet to be investigated. Social exchange theory (Blau, 1964) may offer a valuable framework for these relationships. The latter theory posits that employees and organisations enter into social exchanges with one another when they perceive the other party to be a worthy contributor to the relationship. Therefore, when one party (the organisation) positively impacts another (the employee), the latter should return the favour to honour their part of the exchange. Thus, when organisations positively impact its employees by providing an environment that sufficiently attends to their needs, demands and the things they value and subsequently increase their probability of experiencing positive work-related well-being, employees should upwardly adjust their performance and helping behaviours to express their gratitude.

In addition to the preceding framework, numerous studies suggest that WF elements link to performance (in-role and extra-role) to varying degrees. For example, job satisfaction (Judge, Thoresen, Bono, \& Patton, 2001; LePine, Erez, \& Johnson, 2002), positive affect (Ziegler, Schlett, Casel, \& Diehl, 2012), psychological well-being (Cropanzano \& Wright, 2001) and work engagement (Babcock-Roberson \& Strickland, 2010) have been linked to performance. Furthermore, studies suggest that PEF may indirectly affect in-role performance via psychological need satisfaction (Greguras \& Diefendorff, 2009) and OCB via job satisfaction (Van Dyne et al., 1994).

The following hypotheses stemmed from the discussion:

H1: Person-environment fit positively associates with WF.

H2: WF negatively associates with ITL.

H3: WF positively associates with in-role performance.

H4: WF positively associates with OCB.

H5: Person-environment fit indirectly affects ITL via WF.

H6: Person-environment fit indirectly affects in-role performance via WF.

H7: Person-environment fit indirectly affects OCB via WF. 


\section{Research design Research participants}

A survey was conducted among personnel fulfilling a teaching role in the Sedibeng East and West districts in Gauteng. The teaching profession is a good framework for studies on flourishing, as research that assumes a diseasedriven or dysfunctional behaviour stance (e.g. O'Brennan, Pas, \& Bradshaw, 2017), heavily outweighs a health promotion or positive functioning stance (e.g. Li, Wang, Gao, \& You, 2017). Therefore, more research is needed regarding positive employee behaviours, which include aspects such as strengths, optimal functioning and flourishing (YoussefMorgan \& Luthans, 2014). This is especially important when considering the demands teachers face (e.g. student illdiscipline, fellow educator absenteeism, overinvolvement or lack of parental involvement) and the ever-increasing list of role-players (e.g. department of education, school-governing body, management, parents and learners) they need to satisfy. Approximately 800 surveys were circulated, while 258 were completed adequately ( $32 \%$ response rate). Table 1 provides the sample characteristics.

\section{Measuring instruments}

The Flourishing-at-Work Scale (FAWS; Rautenbach, 2015) measured WF. It comprises 46 items recorded on a 6-point scale ranging from 1 (never) to 6 (every day). Participants were required to respond to questions concerning the regularity with which they experienced particular symptoms at work during the preceding month. The FAWS encompasses three dimensions: emotional well-being, psychological well-being and social well-being. Emotional well-being comprises three dimensions (three items per dimension): positive affect, negative affect and job satisfaction. A sample item for this dimension includes: 'How often did you feel grateful?'. Psychological well-being comprises six dimensions: autonomy satisfaction (three items), competence satisfaction

\begin{tabular}{lcc} 
TABLE 1: Characteristics of the participants $(N=258)$. & \\
\hline Item & Frequency & $\%$ \\
\hline Gender & 62 & 24.0 \\
Male & 90 & 73.7 \\
Female & 6 & 2.3 \\
Missing values & & \\
Age & 106 & 41.1 \\
21-35 years & 129 & 50.0 \\
Older than 35 years & 23 & 8.9 \\
Missing values & & \\
Race & 48 & 18.6 \\
African people & 2 & 0.8 \\
Mixed Race people & 9 & 3.5 \\
Indian people & 192 & 74.4 \\
White people & 1 & 0.4 \\
Other people & 6 & 2.3 \\
Missing values & & \\
Years of service & 104 & 40.3 \\
0-10 years & 134 & 51.9 \\
More than 10 years & 20 & 7.8 \\
Missing values & & \\
\hline
\end{tabular}

(three items), relatedness satisfaction (three items), learning (two items), meaningful work (three items) and engagement (seven items). A sample item for this dimension includes: 'How often did you become enthusiastic about your job?' Social well-being comprises five dimensions (three items per dimension): social acceptance, actualisation, coherence, contribution and integration. A sample item for this dimension includes: 'How often did you feel included at your school?' Rautenbach (2015) confirmed the FAWS's three-factor structure, with rho coefficients ranging from 0.77 to 0.95 .

The Perceived Fit Scale (PFS; Cable \& DeRue, 2002) measured PEF. It contains nine items recorded on a 7-point scale, which ranges from 1 (strongly disagree) to 7 (strongly agree). The PFS comprises three dimensions (three items each): personorganisation fit: 'My personal values match my school's values and culture', need-supplies fit: 'The attributes that I look for in a job are fulfilled very well by my present job', and demands-abilities fit: 'My abilities and training are a good fit with the requirements of my job'. Redelinghuys and Botha (2016) confirmed the PFS's three-factor structure, with rho coefficients ranging from 0.85 to 0.88 .

The Turnover Intention Scale (Sjöberg \& Sverke, 2000) measured ITL. It contains three items recorded on a 5-point scale, which ranges from 1 (strongly disagree) to 5 (strongly agree). Covering a solitary dimension, a sample item includes: 'I feel that I could leave this job'. Janse van Rensburg et al. (2017) yielded a rho coefficient of 0.71.

The In-role Behaviour Scale (Williams \& Anderson, 1991) measured in-role performance. It entails seven items scored on a 7-point scale ranging from 1 (strongly disagree) to 7 (strongly agree). Covering a solitary dimension, a sample item includes: 'I adequately complete assigned duties'. Participants were required to rate their own performance, as external evaluation was prohibited. Redelinghuys et al. (2018) yielded a rho coefficient of 0.73 .

The Organisational Citizenship Behaviour Scale (OCBS; Rothmann, 2010) measured OCB. It entails six items recorded on a 7-point scale, which ranges from 1 (strongly disagree) to 7 (strongly agree). The OCBS comprises two dimensions (three items each): assistance to co-workers: 'I assist others with their duties' and assistance to the organisation: 'I defend the school when other employees criticise it'. Diedericks and Rothmann (2014) confirmed the OCBS's two-factor structure, with adequate reliability coefficients $(>0.70)$.

\section{Research procedure}

Once ethical permissions had been obtained from the necessary authorities, the researchers communicated with the secondary school principals in the selected districts. The researchers arranged dates and times with probable research participants at their respective schools to discuss the study purpose and to obtain informed consent. Paper questionnaires, 
with English as instructional language, were distributed to consenting participants; granting them a 2-week period to complete the questionnaires. Arrangements were made for participants to securely return their questionnaires.

\section{Statistical analysis}

Mplus 7.41 (Muthén \& Muthén, 1998-2016) was applied to analyse the data. The weighted least-squares with mean and variance adjustment (WLSMV) estimator was utilised as it does not assume normally distributed variables, providing the most suitable selection for categorical data modelling. To evaluate the reliability of the measuring battery, rho coefficients (Raykov, 2009) were utilised. The practical significance of results was determined by effect sizes (Cohen, 1988). The confidence interval (CI) level was set at a value of 95\% ( $p \leq 0.05)$ for statistical significance. A measurement model was specified and tested against numerous goodnessof-fit indices. Descriptive statistics were computed with SPSS23 (IBM Corp, 2016).

Four opposing measurement models were specified and tested to make model comparison possible as suggested by Wang and Wang (2012). The best fitting model (Model 1) was respecified as a structural model (Model 6) and compared to opposing structural models. The chi-square statistic, root mean square error of approximation (RMSEA), Tucker-Lewis index (TLI), comparative fit index (CFI) and the weighted root mean square residual (WRMR) were utilised. Comparative fit index and TLI values of $\geq 0.90$ were considered satisfactory. Root mean square error of approximation values of $<0.08$ indicated close model fit.

Discriminant validity of the constructs was assessed using a method proposed by Farrell (2010). To establish discriminant validity, three values are important. Firstly, the correlations between constructs (see the values below the diagonal in Table 3), as this is used to compute squared correlations. Secondly, the average variance extracted (AVE) (see the values on the diagonal in Table 3), which is calculated for each construct by adding the R-square values of each construct item, and then dividing it by the number of items the construct has. For example, person-organisation fit has three items; therefore, its AVE is calculated as follows: $0.838+$ $0.966+0.838 / 3=0.88$. Lastly, squared correlation values (see the values above the diagonal in Table 3) are horizontally and vertically compared to AVE values. Average variance extracted values greater than the squared correlation values, indicate sufficient discriminant validity.

Indirect effects were assessed in Mplus 7.41. Bootstrapping with 10000 samples was applied to construct two-sided biascorrected 95\% CIs (Hayes, 2018). Lower and upper CIs were conveyed.

\section{Ethical consideration}

Authorisation for the study was acquired from the Gauteng Department of Education, the Sedibeng East and
West District offices, as well as ethical clearance from the North-West University's Ethics Committee.

\section{Results \\ Measurement model testing}

Confirmatory factor analyses were carried out with the scales through Mplus 7.41 (Muthén \& Muthén, 1998-2016). A hypothesised measurement model (Model 1) was specified and tested against opposing models (Models 2-5) to establish which model fitted the data best.

The model comprised one third-order factor (WF), two second-order factors (PEF and OCB) and two first-order factors (ITL: measured by three observed variables, and inrole performance: measured by seven observed variables). WF comprised three second-order factors: emotional wellbeing, psychological well-being, and social well-being. Emotional well-being comprised three first-order factors (each measured by three observed variables): positive affect, negative affect and job satisfaction. Psychological well-being comprised six first-order factors: autonomy, competence, relatedness (each measured by three observed variables), learning (measured by two observed variables), meaningful work (measured by three observed variables) and engagement (measured by seven observed variables). Social well-being comprised five first-order factors (each measured by three observed variables): social contribution, integration, actualisation, acceptance and coherence. Person-environment fit comprised three first-order factors (each measured by three observed variables): person-organisation fit, needssupplies fit and demands-abilities fit. Organisational citizenship behaviour comprised two first-order factors (each measured by three observed variables): citizenship behaviour towards co-workers and citizenship behaviour towards the organisation. All latent variables were correlated.

A $\chi^{2}$ of $4668.46(d f=2313)$ was achieved for the original measurement model. Acceptable CFI and TLI fit indices (both 0.93) were achieved. The RMSEA (0.06) and $\chi^{2} / d f(2.02)$ were acceptable, while the WRMR (1.62) value was lower compared to the alternative models.

Following the same blueprint as Model 1, Models 2-5 were similarly specified and tested, with minor changes to the models. In Model 2, PEF consisted of one first-order variable: fit (measured by nine observed variables). In Model 3, WF consisted of 3 second-order variables: emotional well-being (measured by 9 observed variables), psychological wellbeing (measured by 21 observed variables) and social wellbeing (measured by 15 observed variables). In Model 4, WF consisted of two second-order variables: hedonic well-being (measured by nine observed variables) and eudaimonic wellbeing (measured by 36 observed variables). In Model 5, PEF and WF jointly consisted of one first-order variable: wellbeing (measured by 54 observed variables).

Table 2 presents the goodness-of-fit statistics for the five competing measurement models described above. 
TABLE 2: Goodness-of-fit statistics of competing measurement models.

\begin{tabular}{|c|c|c|c|c|c|c|c|}
\hline \multirow[t]{2}{*}{ Model } & \multirow[t]{2}{*}{$\chi^{2}$} & \multirow[t]{2}{*}{$d f$} & \multirow[t]{2}{*}{ TLI } & \multirow[t]{2}{*}{ CFI } & \multicolumn{2}{|c|}{ RMSEA } & \multirow[t]{2}{*}{ WRMR } \\
\hline & & & & & Estimate & $90 \% \mathrm{Cl}$ & \\
\hline 1 & $4668.462 *$ & 2313 & 0.93 & 0.93 & 0.06 & $0.060,0.065$ & 1.62 \\
\hline 2 & $5028.588 *$ & 2316 & 0.92 & 0.92 & 0.07 & $0.065,0.070$ & 1.74 \\
\hline 3 & $6133.391 *$ & 2327 & 0.88 & 0.89 & 0.08 & $0.077,0.082$ & 2.03 \\
\hline 4 & $7080.640 *$ & 2328 & 0.85 & 0.86 & 0.09 & $0.087,0.091$ & 2.27 \\
\hline 5 & 8894.941* & 2337 & 0.80 & 0.80 & 0.10 & $0.102,0.107$ & 2.68 \\
\hline
\end{tabular}

$\chi^{2}$, chi-square statistic; $d f$, degrees of freedom; TLI, Tucker-Lewis index; Cl, confidence interval; CFI, comparative fit index; RMSEA, root mean square error of approximation; WRMR, weighted root mean square residual.

\section{Descriptive statistics, reliabilities, correlation coefficients and discriminant validity}

Table 3 reports the descriptive statistics, reliabilities, correlation coefficients and discriminant validity of the constructs.

The reliabilities of the measuring instruments were acceptable, ranging from 0.75 to 0.94 (Nunnally \& Bernstein, 1994). All the PEF dimensions were practically and statistically significantly related to the three emotional wellbeing dimensions, six psychological well-being dimensions and five social well-being dimensions, ranging from medium to large effects. Person-environment fit dimensions were practically and statistically significantly related to job satisfaction (emotional well-being), autonomy satisfaction (psychological well-being) and social actualisation (social well-being) with a large effect.

Most of the flourishing dimensions were practically and statistically significantly related to ITL (large effects), except for negative affect $(0.46)$, competence $(-0.43)$, meaning $(-0.48)$ and learning $(-0.48)$. Most flourishing dimensions were practically and statistically significantly related to inrole performance with a medium effect, except for negative affect (-0.29) and competence (0.28). Most flourishing dimensions were practically and statistically significantly related to OCB (to co-workers) with a medium effect, as well as OCB (to the organisation), ranging from medium to large effects.

Discriminant validity is supported. Table 3 shows that the AVE per construct (on the diagonal) was greater than the squared correlation values (above the diagonal).

\section{Structural model testing}

A structural model (Model 6) was specified and tested based on Model 1 (the best fitting measurement model). No difference in the chi-square values (4668.462) of the best fitting measurement and structural models, indicated acceptable model specification. Model 6 yielded the following fit statistics: $\chi^{2}=4668.462 ; d f=2313 ; p<0.001$; TLI $=0.93$; $\mathrm{CFI}=0.93$; RMSEA $=0.06$ (90\% CI: 0.060, 0.065); WRMR = 1.62. As a result of the cross-sectional nature of the study, two opposing models (6a and $6 \mathrm{~b}$ ) were tested for comparable fit purposes, as suggested by Hancock and Mueller (2010). Model 6a: $\chi^{2}=10761.737 ; d f=2314 ; p<0.001 ; \mathrm{TLI}=0.73$; CFI = 0.75 ; RMSEA $=0.12$ (90\% CI: 0.117, 0.121); WRMR $=3.31$.
Model 6b: $\chi^{2}=4691.298 ; d f=2316 ; p<0.001 ;$ TLI $=0.93$; $\mathrm{CFI}=0.93$; RMSEA $=0.06$ (90\% CI: 0.060, 0.066); WRMR = 1.64. The WLSMV estimator was used in these calculations. The chi-square values for WLSMV cannot be used for chi-square difference testing (Satorra \& Bentler, 2010). Therefore, the Difftest Mplus function was utilised. Table 4 illustrates the difference testing of the opposing structural models and designates Model $6 \mathrm{~b}$ as the best fitting opposing model.

Figure 1 illustrates the standardised path coefficients estimated by Mplus 7.41 (Muthén \& Muthén, 1998-2016) for Model 6.

Figure 1 illustrates the standard path coefficients found with PEF as independent variable and WF, ITL, in-role performance and OCB as dependent variables and also WF as an independent variable with ITL, in-role performance and OCB as dependent variables.

For the model portion predicting WF, PEF's path coefficient ( $\beta=0.82 ; p \leq 0.01)$ was statistically significant and displayed the anticipated sign. Therefore, Hypothesis 1 is accepted.

For the model portion predicting ITL, the path coefficients of PEF $(\beta=-0.60 ; p \leq 0.01)$ and WF $(\beta=-0.22 ; p \leq 0.05)$ were statistically significant and displayed the anticipated sign. Therefore, Hypothesis 2 is accepted.

For the model portion predicting in-role performance, WF's path coefficient $(\beta=0.34 ; p \leq 0.01)$ was statistically significant and displayed the anticipated sign. Therefore, Hypothesis 3 is accepted.

For the model portion predicting OCB, WF's path coefficient $(\beta=0.54 ; p \leq 0.01)$ was statistically significant and displayed the anticipated sign. Therefore, Hypothesis 4 is accepted.

Regarding effect sizes (Cohen, 1988), the model accounted for the following percentages of variance explained $\left(R^{2}\right)$ : $\mathrm{WF}=67 \%$ (large effect), ITL $=62 \%$ (large effect), in-role performance $=21 \%$ (medium effect) and OCB $=40 \%$ (large effect).

\section{Testing indirect effects}

To establish whether PEF indirectly affected ITL, in-role performance and OCB, the authors used Hayes's (2018) guidelines. 


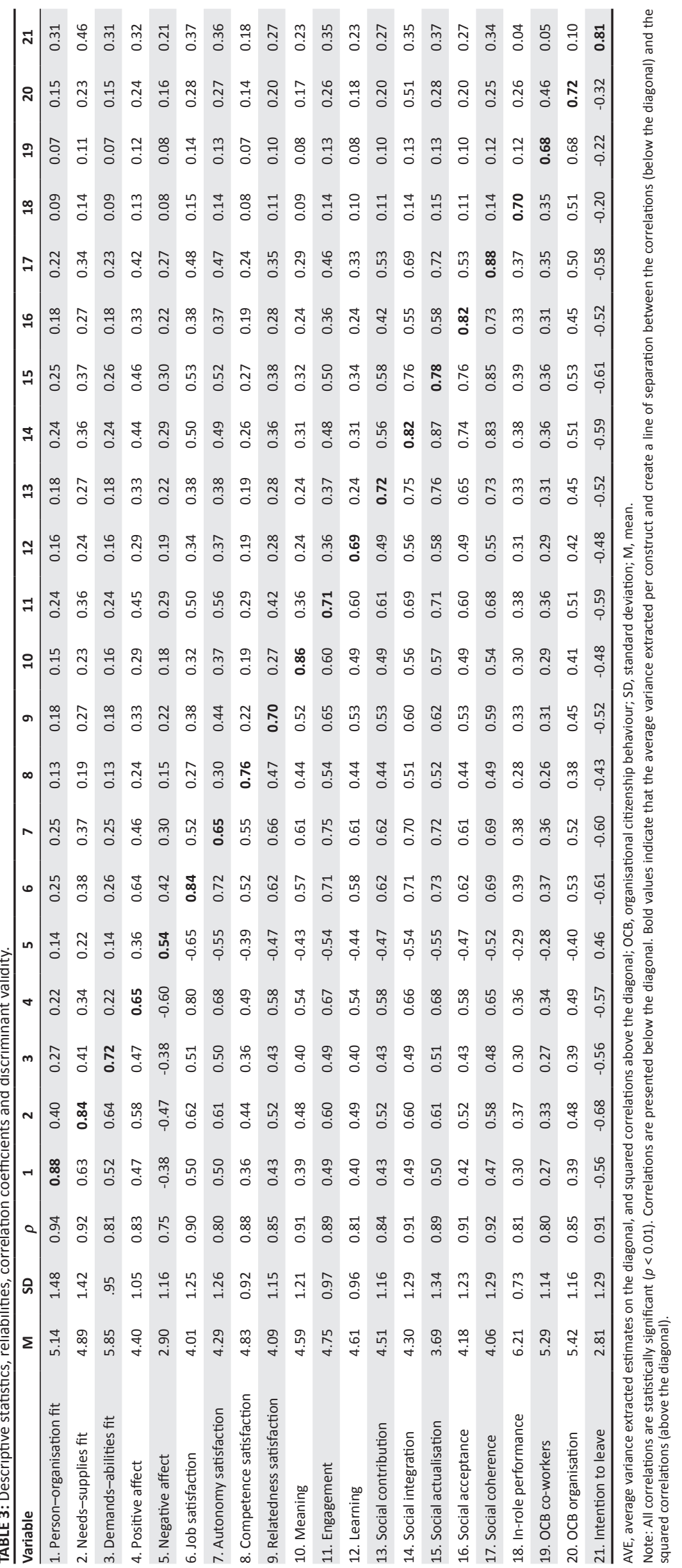


TABLE 4: Difference testing for competing structural models.

\begin{tabular}{lccc}
\hline Model & $\Delta \chi^{2}$ & $\Delta d f$ & $p$ \\
\hline Model 6a & 277.888 & 1 & $<0.0001^{*}$ \\
Model 6b & 23.568 & 3 & $<0.0001^{*}$ \\
\hline
\end{tabular}

$*, p<0.01$.

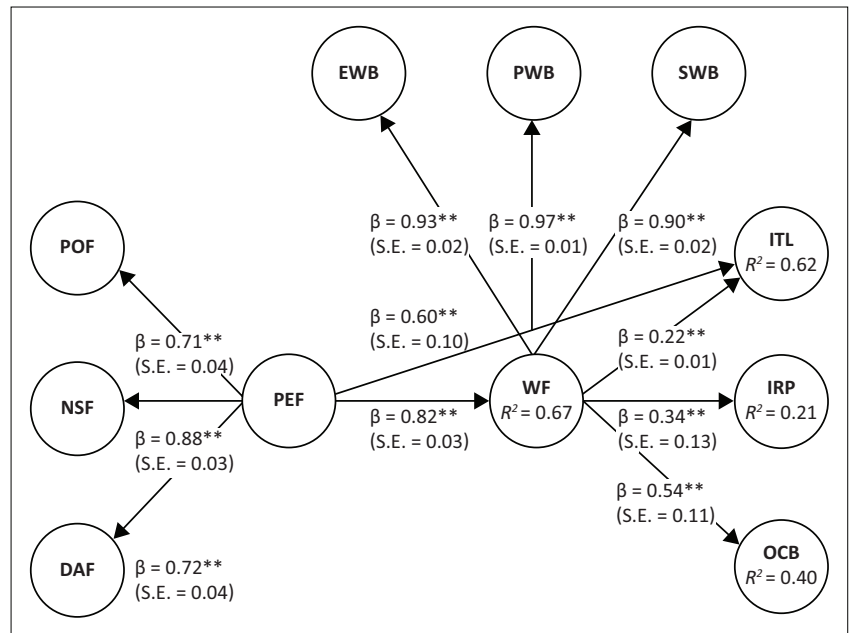

POF, person-organisation fit; NSF, needs-supplies fit; DAF, demands-abilities fit; PEF, person-environment fit; WF, workplace flourishing; EWB, emotional well-being; $P W B$, psychological well-being; SWB, social well-being; ITL, intention to leave; IRP, in-role performance; $\mathrm{OCB}$, organisational citizenship behaviour; $\mathrm{SE}$, standard error; $R^{2}$, variance explained; $ß$, regression coefficients.

$*, p<0.05 ; * *, p<0.01$.

FIGURE 1: The structural model - Standardised solution with standard errors in parentheses.

TABLE 5: Indirect effect of person-environment fit on intention to leave, in-role performance and organisational citizenship behaviour via workplace flourishing.

\begin{tabular}{|c|c|c|c|c|}
\hline Variable & Estimate & SE & $p$ & $95 \% \mathrm{BC} \mathrm{Cl}$ \\
\hline Indirect effect on intention to leave & 0.18 & 0.12 & 0.12 & $0.33,0.23$ \\
\hline Indirect effect on in-role performance & 0.28 & 0.12 & 0.02 & $0.05,0.55$ \\
\hline $\begin{array}{l}\text { Indirect effect on organisational } \\
\text { citizenship behaviour }\end{array}$ & 0.44 & 0.13 & 0.00 & $0.21,0.68$ \\
\hline
\end{tabular}

$\mathrm{SE}$, standard error; $\mathrm{BC} \mathrm{Cl}$, bias-corrected confidence interval.

Table 5 shows the indirect effect of PEF on ITL, in-role performance and OCB. Person-environment fit had a statistically significant indirect effect $(p \leq 0.05)$ on in-role performance and OCB $(p \leq 0.01)$ via WF. Person-environment fit did not have a statistically significant indirect effect $(p>0.05)$ on ITL via WF. Therefore, Hypothesis 6 and 7 are accepted. Hypothesis 5 is rejected.

\section{Discussion}

The study aim was to examine relationships among PEF, WF, ITL, in-role performance and OCB. When employees fit, feel well and function well both psychologically and socially, positive outcomes ensue (i.e. lower ITL, higher in-role performance and $\mathrm{OCB})$.

Results confirmed WF's three-factor structure, endorsing its construct validity beyond the fast-moving consumer goods industry (Rautenbach, 2015) and tertiary education sector (Janse van Rensburg et al., 2017). Flourishing at work consisted of emotional well-being (job satisfaction, positive affect and low negative affect), psychological well-being (autonomy satisfaction, competence satisfaction, relatedness satisfaction, meaning, engagement and learning) and social well-being (social contribution, integration, actualisation, acceptance and coherence). Similar to previous studies (Janse van Rensburg et al., 2017; Rautenbach, 2015), all the FAWS dimensions yielded acceptable reliability coefficients, varying from 0.75 to 0.92 . Discriminant validity was also supported as the AVE per construct was greater than the associated squared correlation values.

The results indicated that PEF positively associated with WF. Therefore, when employees perceive high similarity between their own values and the values of their organisation, between the compensation they receive in response to the work they deliver, and similarity between their job demands and their capabilities, they should experience elevated emotional well-being, psychological well-being and social well-being levels at work. The results are consistent with the TWA (Dawis \& Lofquist, 1984), the ASA theory (Schneider, 1987) and other PEF theories, indicating that personenvironment congruence equates to positive outcomes. The results also support the notion of cognitive appraisal theories of affect (Roseman, Spindel, \& Jose, 1990; Scherer, 1999) that cognitive circumstantial evaluations yield affective responses and the social identity theory (Tajfel \& Turner, 1986) which proposes that workers who experience fit with their organisation's values, become part of a 'psychological group'. This also concurs with prior findings (Janse van Rensburg et al., 2017).

WF negatively associated with ITL. Numerous theories suggest that WF elements relate to ITL. Lee and Mitchell's (1994) unfolding model of voluntary turnover, as well as Mobley's (1977) turnover model, indicate that dissatisfied employees will start to explore other possibilities through a range of evaluation processes. Consistent with previous findings (Diedericks \& Rothmann, 2014; Janse van Rensburg et al., 2017; Rothmann, 2013), employees will be less inclined to consider vacating their job when they flourish in the workplace.

WF positively associated with in-role performance and OCB. Numerous theories can explain the flourishingperformance relationship. The happy and/or productive worker thesis suggests that happy (predominantly measured by job satisfaction) employees are productive employees. Quantitative and qualitative reviews of the job satisfactionjob performance relationship have also shown that job satisfaction positively associates with job performance (Judge et al., 2001). Studies have also shown that psychological wellbeing predicts job performance (Cropanzano \& Wright, 2001). Furthermore, the social exchange theory (Blau, 1964) proposes that when one party (the organisation) positively impacts another (the employee), the latter should return the favour to honour their part of the exchange. Therefore, employees who perceive that their needs, demands and the things they value are sufficiently attended to are more likely to experience a positive work environment, which should propel them towards better performance (in-role and extra-role). 
Results showed a direct association between PEF and ITL, proposing that PEF reduces participant intent to leave, regardless of their flourishing levels. The ASA model (Schneider, 1987) suggests that employees who experience work environment incongruence should be more inclined to leave. Similarly, WF significantly associated with ITL, regardless of employee PEF levels. Thus, PEF and WF, both in their own right and independently, significantly associated with individuals' thoughts of leaving their organisation. As individuals experience fit with their school and job aspects, and experience links within the organisation (e.g. social integration), they have much more to sacrifice when leaving the school, resulting in lower ITL. This is inconsistent with previous findings (Janse van Rensburg et al., 2017). A possible explanation for this inconsistency could be ascribed to increased model complexity.

With regard to the indirect effect of PEF on in-role performance and OCB via WF, respectively, results confirmed this effect. Hence, PEF's association with in-role performance and OCB is an indirect one, suggesting that PEF increases participant performance (in-role and extra-role), as long as participant flourishing levels remain sufficiently high. Therefore, PEF should first elevate employee flourishing levels to subsequently increase in-role performance and OCB. Although the preceding associations have not been studied before, they seem consistent with Fishbein and Ajzen's (1975) framework which contends that beliefs precede attitudes, intentions and ultimately behaviours.

\section{Conclusion}

\section{Limitations}

Several study limitations are prominent. Firstly, the crosssectional research approach impedes the assessment of causality among the variables under scrutiny. Secondly, the study did not assess interpersonal PEF aspects such as person-group and person-supervisor fit. Thirdly, because of certain restrictions (e.g. occupation and geographical location), the generalisation of findings to other settings should proceed with caution. Lastly, a specific modelling strategy was used to assess the constructs, another strategy (e.g. bifactor modelling) may possibly yield different results.

\section{Recommendations}

In practice, the probability of employees experiencing different levels (poor, average, and good) of fit and wellbeing is highly plausible. Therefore, it is unrealistic to expect organisations to have a universal blueprint for collectively addressing the fit and well-being of their workforce because of the diversity of employee needs, beliefs, perceptions and attitudes. Although organisations should have generic fit and well-being initiatives embedded within their strategic framework (e.g. change management, organisational development, training and development, recruitment and selection), they should continually update and modify these strategies to ensure a healthy balance is maintained between individual (values, abilities and needs) and environmental (values, demands, and supplies) characteristics. This will lay the foundation for a favourable work environment, an environment where employees can experience a sense of acceptance, enjoyment, integration, meaningfulness and relatedness (among others). When such an environment is institutionalised, talent retention and performance should follow.

Future studies should aim to explore additional outcomes and antecedents related to WF. Research should also aim to assess the causality between the constructs, as none of the constructs is static in nature. A bifactor modelling strategy could provide more clarity on the psychometric properties of the FAWS (Rautenbach, 2015) and PFS (Cable \& DeRue, 2002) in larger samples.

\section{Acknowledgements Competing interests}

The authors declare that they have no financial or personal relationships that may have inappropriately influenced them in writing this article. The views expressed in this article are our own and do not reflect the official position of the institution or funder.

\section{Authors' contribution}

K.R. coordinated the data collection process. S.R. assisted with data analysis and interpretation. K.R., S.R. and E.B. made contributions regarding the conceptualisation, as well as writing and editing, of the article.

\section{References}

Adnot, M., Dee, T., Katz, V., \& Wyckoff, J. (2017) Teacher turnover, teacher quality, and student achievement in DCPS. Educational Evaluation and Policy Analysis, 39(1), 54-76 https://doi.org/10.3102/0162373716663646

Alarcon, G. M., \& Edwards, J. M. (2011). The relationship of engagement, job satisfaction and turnover intentions. Stress and Health, 27(3), 294-298. https:// doi.org/10.1002/smi.1365

Babcock-Roberson, M. E., \& Strickland, O. J. (2010). The relationship between charismatic leadership, work engagement, and organizational citizenship behaviors. The Journal of Psychology, 144(3), 313-326. https://doi.org/10.1080/ 00223981003648336

Barrick, M. R., Mount, M. K., \& Li, N. (2013). The theory of purposeful work behavior: The role of personality, higher-order goals, and job characteristics. Academy of Management Review, 38(1), 132-153. https://doi.org/10.5465/amr.2010.0479

Blau, P. M. (1964). Exchange and power in social life. New York: Wiley.

Borman, W. C., \& Motowidlo, S. J. (1997). Task performance and contextual performance: The meaning for personnel selection research. Human Performance, 10, 99-109. https://doi.org/10.1207/s15327043hup1002_3

Cable, D. M., \& DeRue, D. S. (2002). The convergent and discriminant validity of subjective fit perceptions. Journal of Applied Psychology, 87(5), 875-884. https:// doi.org/10.1037/0021-9010.87.5.875

Chen, C., Yen, C., \& Tsai, F. C. (2014). Job crafting and job engagement: The mediating role of person-job fit. International Journal of Hospitality Management, 37, 21-28. https://doi.org/10.1016/j.ijhm.2013.10.006

Cohen, J. (1988). Statistical power analysis for the behavioral sciences (2nd ed.). Hillsdale, NJ: Lawrence Erlbaum Associates.

Coyle-Shapiro, J. A. (2002). A psychological contract perspective on organizational citizenship behavior. Journal of Organizational Behavior, 23(8), 927-946. https:// doi.org/10.1002/job.173

Cropanzano, R., \& Wright, T. A. (2001). When a 'happy' worker is really a 'productive' worker: A review and further refinement of the happy-productive worker thesis. Consulting Psychology Journal: Practice and Research, 53, 182-199. https://doi. org/10.1037/1061-4087.53.3.182

Dawis, R. V., \& Lofquist, L. H. (1984). A psychological theory of adjustment. Minneapolis, MN: University of Minnesota Press. 
Deci, E. L., \& Ryan, R. M. (1985). Intrinsic motivation and self-determination in human behavior. New York: Plenum.

Diedericks, E., \& Rothmann, S. (2014). Flourishing of information technology professionals: Effects on individual and organisational outcomes. South African Journal of Business Management, 45(1), 27-41. Retrieved from http://hdl.handle. net/10520/EJC151238

Duffy, R. D., Autin, K. L., \& Bott, E. M. (2015). Work volition and job satisfaction Examining the role of work meaning and person-environment fit. The Career Development Quarterly, 63, 126-140. https://doi.org/10.1002/cdq.12009

Farrell, A. M. (2010). Insufficient discriminant validity: A comment on Bove, Pervan Beatty, and Shiu (2009). Journal of Business Research, 63, 324-327. https://doi. org/10.1016/j.jbusres.2009.05.003

Fishbein, M., \& Ajzen, I. (1975). Belief, attitude, intention, and behavior: An introduction to theory and research. Reading, MA: Addison-Wesley.

Gabriel, A. S., Diefendorff, J. M., Chandler, M. M., Moran, C. M., \& Greguras, G. J. (2014) The dynamic relationships of work affect and job satisfaction with perceptions of fit. Personnel Psychology, 67(2), 389-420. https://doi.org/10.1111/peps.12042

Grant, A. M. (2008). Designing jobs to do good: Dimensions and psychological consequences of prosocial job characteristics. The Journal of Positive Psychology, consequences of prosocial job characteristics. The Journal of

Greguras, G. J., \& Diefendorff, J. M. (2009). Different fits satisfy different needs: Linking person-environment fit to employee commitment and performance using self-determination theory. Journal of Applied Psychology, 94, 465-477. https:// self-determination theory.
doi.org/10.1037/a0014068

Hancock, G. R., \& Mueller, R. O. (2010). The reviewer's guide to quantitative methods in the social sciences. New York: Routledge.

Hayes, A. F. (2018). Introduction to mediation, moderation, and conditional process analysis: A regression-based approach (2nd ed.). New York: Guilford Press.

Hoffman, B. J., \& Woehr, D. J. (2006). A quantitative review of the relationship between person-organization fit and behavioral outcomes. Journal of Vocational Behavior, 68, 389-399. https://doi.org/10.1016/j.jvb.2005.08.003

Hom, P. W., Lee, T. W., Shaw, J. D., \& Hausknecht, J. P. (2017). One hundred years of employee turnover theory and research. Journal of Applied Psychology, 102(3), 530-545. https://doi.org/10.1037/apl0000103

IBM Corp. (2016). IBM SPSS statistics for Windows, Version 23.0. Armonk, NY: IBM Corp.

Janik, M., \& Rothmann, S. (2015). Meaningful work and secondary school teachers' intention to leave. South African Journal of Education, 35(2), 1-13. https://doi. org/10.15700/saje.v35n2a1008

Janse van Rensburg, C., Rothmann, S., \& Diedericks, E. (2017). Person-environment fit, flourishing and intention to leave in universities of technology in South Africa. SA Journal of Industrial Psychology, 43, a1422. https://doi.org/10.4102/sajip. v43i0.1422

Judge, T. A., Thoresen, C. J., Bono, J. E., \& Patton, G. K. (2001). The job satisfaction-job performance relationship: A qualitative and quantitative review. Psychological Bulletin, 127, 376-407. https://doi.org/10.1037/0033-2909.127.3.376

Kahn, W., \& Heaphy, E. D. (2014). Relational contexts of personal engagement at work. In C. Truss, R. Delbridge, E. Soane, K. Alfes, \& A. Shantz (Eds.), Employee engagement in theory and practice (pp. 163-179). Abingdon: Routledge.

Keyes, C. L. M. (1998). Social well-being. Social Psychology Quarterly, 61, 121-140. https://doi.org/10.2307/2787065

Keyes, C. L. M. (2002). The mental health continuum: From languishing to flourishing in life. Journal of Health and Social Behavior, 43, 207-222. https://doi. org/10.2307/3090197

Keyes, C. L. M. (2005). Mental illness and/or mental health? Investigating axioms of the complete state model of health. Journal of Consulting and Clinical Psychology, 73(3), 539-548. https://doi.org/10.1037/0022-006X.73.3.539

Kristof-Brown, A. L., Zimmerman, R. D., \& Johnson, E. C. (2005). Consequences of individuals' fit at work: A meta-analysis of person-job, person-organization, person-group, and person-supervisor fit. Personnel Psychology, 58, 281-342. https://doi.org/10.1111/j.1744-6570.2005.00672.x

Lambert, S. J. (2006). Both art and science: Employing organizational documentation in workplace-based research. In M. Pitt-Catsouphes, E. E. Kossek, \& S. Sweet (Eds.), The work and family handbook: Multi-disciplinary perspectives, methods, and approaches (pp. 503-525). Mahwah, NJ: Lawrence Erlbaum Associates.

Lee, T. W., \& Mitchell, T. R. (1994). An alternative approach: The unfolding model of voluntary employee turnover. Academy of Management Review, 19, 51-89. Retrieved from https://www.jstor.org/stable/258835

LePine, J. A., Erez, A., \& Johnson, D. E. (2002). The nature and dimensionality of organizational citizenship behavior: A critical review and meta-analysis. Journal of Applied Psychology, 87, 52-65. https://doi.org/10.1037/0021-9010.87.1.52

Li, M., Wang, Z., Gao, J., \& You, X. (2017). Proactive personality and job satisfaction: The mediating effects of self-efficacy and work engagement in teachers. Curren Psychology, 36(1), 48-55. https://doi.org/10.1007/s12144-015-9383-1

Locke, E. A. (1976). The nature and causes of job satisfaction. In M. D. Dunnette (Ed.), Handbook of industrial and organizational psychology (pp. 1297-1343). Chicago, IL: Rand McNally.

Mitchell, T. R., Holtom, B. C., Lee, T. W., Sablynski, C. J., \& Erez, M. (2001). Why people stay: Using job embeddedness to predict voluntary turnover. Academy of Management Journal, 44, 1102-1121. https://doi.org/10.2307/3069391

Mobley, W. H. (1977). Intermediate linkages in the relationship between job satisfaction and employee turnover. Journal of Applied Psychology, 62, 237-240. https://doi.org/10.1037/0021-9010.62.2.237
Muthén, L. K., \& Muthén, B. O. (1998-2016). Mplus user's quide (7th ed.). Los Angeles, CA: Muthén \& Muthén.

Nunnally, J. C., \& Bernstein, I. H. (1994). Psychometric theory (3rd ed.). New York: McGraw-Hill.

O'Brennan, L., Pas, E., \& Bradshaw, C. (2017). Multilevel examination of burnout among high school staff: Importance of staff and school factors. School Psychology Review, 46(2), 165-176. https://doi.org/10.17105/SPR-2015-0019.V46-2

Oh, I. S., Guay, R. P., Kim, K., Harold, C. M., Lee, J. H., Heo, C. G., \& Shin, K. H. (2014) Fit happens globally: A meta-analytic comparison of the relationships of personenvironment fit dimensions with work attitudes and performance across Eas Asia, Europe, and North America. Personnel Psychology, 67, 99-152. https://doi. org/10.1111/peps.12026

Peng, J., Lee, Y., \& Tseng, M. (2014). Person-organization fit and turnover intention Exploring the mediating effect of work engagement and the moderating effect of demand-ability fit. Journal of Nursing Research, 22, 1-11. https://doi.org/ 10.1097/jnr.0000000000000019

Rautenbach, C. (2015). Flourishing of employees in a fast moving consumable goods environment (Doctoral thesis). Vanderbijlpark: North-West University. Retrieved from http://hdl.handle.net/10394/17030

Raykov, T. (2009). Interval estimation of revision effect on scale reliability via covariance structure modeling. Structural Equation Modeling, 16, 539-555. https://doi.org/10.1080/10705510903008337

Redelinghuys, K., \& Botha, E. (2016). Person-environment fit, job satisfaction and intentions to leave: The moderating effect of leader empowering behaviour. Journal of Psychology in Africa, 26(1), 11-21. https://doi.org/10.1080/14330237. 2015.1101273

Redelinghuys, K., Rothmann, S., \& Botha, E. (2018). Flourishing-at-Work: The role of positive organizational practices. Psychological Reports. https://doi.org/10.1177/ 0033294118757935

Rojas, M., \& Veenhoven, R. (2013). Contentment and affect in the estimation of happiness. Social Indicators Research, 110(2), 415-431. https://doi.org/10.1007/ s11205-011-9952-0

Roseman, I. J., Spindel, M. S., \& Jose, P. E. (1990). Appraisals of emotion-eliciting events: Testing a theory of discrete emotions. Journal of Personality and Socia Psychology, 59, 899-915. https://doi.org/10.1037/0022-3514.59.5.899

Rothmann, S. (2010). The reliability and validity of measuring instruments of happiness in the Southern African context (Unpublished research report). Vanderbijlpark: North-West University.

Rothmann, S. (2013). From happiness to flourishing at work: A Southern African perspective. In M. P. Wissing (Ed.), Well-being research in South Africa: Crosscultural advances in positive psychology (Vol. 4, pp. 123-152). Dordrecht: Springer.

Ryff, C. D., \& Singer, B. (1998). The contours of positive human health. Psychological Inquiry, 9(1), 1-28. https://doi.org/10.1207/s15327965pli0901_1

Satorra, A., \& Bentler, P. M. (2010). Ensuring positiveness of the scaled difference chisquare test statistic. Psychometrika, 75, 243-248. https://doi.org/10.1007/ s11336-009-9135-y

Scherer, K. R. (1999). Appraisal theory. In T. Dalgleish \& M. J. Power (Eds.), Handbook of cognition and emotion (pp. 637-663). New York: John Wiley \& Sons Ltd.

Schneider, B. (1987). The people make the place. Personnel Psychology, 40, 437-453. https://doi.org/10.1111/j.1744-6570.1987.tb00609.x

Seligman, M. E. P. (2011). Flourish: A new understanding of happiness and wellbeing - And how to achieve them. London: Nicholas Brealey.

Sjöberg, A., \& Sverke, M. (2000). The interactive effect of job involvement and organizational commitment on job turnover revisited: A note on the mediating
role of turnover intention. Scandinavian Journal of Psychology, 41, 247-252. role of turnover intention. Scandinavian
$\mathrm{https} / / /$ doi.org/10.1111/1467-9450.00194

Spreitzer, G. M., Lam, C. F., \& Fritz, C. (2010). Engagement and human thriving: Complementary perspectives on energy and connections to work. In A. B. Bakker \& M. P. Leiter (Eds.), Work engagement: $A$ handbook of essential theory and research (pp. 132-146). New York: Psychology Press.

Steinhardt, M. A., Smith Jaggars, S. E., Faulk, K. E., \& Gloria, C. T. (2011). Chronic work stress and depressive symptoms: Assessing the mediating role of teacher burnout. Stress and Health, 27(5), 420-429. https://doi.org/10.1002/smi.1394

Tajfel, H., \& Turner, J. C. (1986). The social identity theory of intergroup behavior In S. Worchel \& L. W. Austin (Eds.), Psychology of intergroup relations (pp. 7-24). Chicago, IL: Nelson-Hall.

Tett, R. P., \& Meyer, J. P. (1993). Job satisfaction, organizational commitment, turnover intention, and turnover: Path analyses based on meta-analytic findings. Personnel Psychology, 46, 259-293. https://doi.org/10.1111/j.1744-6570.1993. tb00874.x

Thoresen, C. J., Kaplan, S. A., Barsky, A. P., Warren, C. R., \& De Chermont, K. (2003) The affective underpinnings of job perceptions and attitudes: A meta-analytic review and integration. Psychological Bulletin, 129(6), 914-945. https://doi. org/10.1037/0033-2909.129.6.914

Turner, J. C. (1984). Social identification and psychological group formation. In H. Tajfel (Ed.), The social dimension: European developments in social psychology (pp. 518-538). Cambridge: Cambridge University Press.

Van Dyne, L., Graham, J. W., \& Dienesch, R. M. (1994). Organizational citizenship behavior: Construct redefinition, measurement, and validation. Academy of Management Journal, 37(4), 765-802. https://doi.org/10.2307/256600

Verquer, M. L., Beehr, T. A., \& Wagner, S. H. (2003). A meta-analysis of relations between person-organization fit and work attitudes. Journal of Vocational Behavior, 63, 473-489. https://doi.org/10.1016/S0001-8791(02)00036-2 
Wang, J., \& Wang, X. (2012). Structural equation modeling: Applications using Mplus. Chichester: Wiley.

Weiss, H. M., \& Cropanzano, R. (1996). Affective Events Theory: A theoretical discussion of the structure, causes and consequences of affective experiences at work. In B. M. Staw \& L. L. Cummings (Eds.), Research in organizational behavior: An annual series of analytical essays and critical reviews (Vol. 18, pp. 1-74). US: Elsevier Science/JAI Press.

Wheeler, A. R., Gallagher, V. C., Brouer, R. L., \& Sablynski, C. J. (2007). When personorganization (mis)fit and (dis)satisfaction lead to turnover: The moderating role of perceived job mobility. Journal of Managerial Psychology, 22(2), 203-219. https:// doi.org/10.1108/02683940710726447
Williams, L. J., \& Anderson, S. E. (1991). Job satisfaction and organizational commitment as predictors of organizational citizenship and in-role behaviors. Journal of Management, 17(3), 601-617. https://doi.org/10.1177/014920639 101700305

Youssef-Morgan, C. M., \& Luthans, F. (2014). Psychological capital and well-being. Stress and Health, 31, 180-188. https://doi.org/10.1002/smi.2623

Ziegler, R., Schlett, C., Casel, K., \& Diehl, M. (2012). The role of job satisfaction, job ambivalence, and emotions at work in predicting organizational citizenship behavior. Journal of Personnel Psychology, 11, 176-190. https://doi.org/10.1027/ 1866-5888/a000071 